\title{
FOCUS
}

\section{PEACE IN THE ISLAMIC TRADITION: ONE VISION, MULTIPLE PATHWAYS}

\author{
Mohammad Hashim Kamali*
}

\begin{abstract}
This article begins by looking at peace as a theological principle, before proceeding to explore peace from various other angles, such as peace through inclusivity, peace through non-violence, peace through equity and fair treatment of others. There is also an elaborate articulation of methods for the peaceful resolution of conflicts, including counselling (nasihah), conciliation (sulh), arbitration (tahkim), forgiveness ('afwa), and truce (al-hudnah). After reviewing these, the discussion then presents a selection of Islamic legal maxims (qawa'id kulliyyah fiqhiyyah) that accentuate the primacy of peace in Islam. Legal maxims are concise epithetic declarations of principles that accentuate the higher goals and purposes of Islam. We conclude with a set of actionable recommendations.

Keywords: Islam, peace, equity, conciliation, non-violence, Qur'an, Sufism, jihad
\end{abstract}

\section{Introductory Remarks}

Peace in our time is being challenged by persistent imbalances, wars, terrorism, widening inequalities, environmental degradation and an international system that has become far too polarised. This suggests that humans have not allowed themselves to be transformed by their respective traditions, nor by the harrowing experiences of these turbulent times.

Religion and peace are intimately co-related in almost all major world traditions. Peace from the Islamic perspective is not merely the absence of war but an ideal state of inward and outward equilibrium and harmony achievable through striving against egotism, racism, economic exploitation and social injustice. Peace through equity and justice is a cardinal objective of Islam, often championed by Muslim intellectuals and the vast majority of ordinary Muslims. The events of September 11, 2001, have, however, focused the world's eyes on Muslim terrorists, leading to a much distorted view of Islam and Muslims. 
Islam's fundamentally peaceful nature is, however, easy to illustrate. Jihad, for example, abusive interpretations of it notwithstanding, is primarily an instrument of peaceful self-discipline. The pathways to peace are also enriched by Islam's rich tradition of Sufism and its wealth of teachings on human fraternity, compassion, justice, beneficence, honouring one's neighbour, avoidance of harm to others, and a dignified resistance to provocation. A coercive narrative of peace through subjugation also exists but which is exceptional to Islam's normative advocacy of pacifism that is sustained by our readings of Islam's history and scripture.

Insofar as Muslims feel that they are "under siege," radical and authoritarian understandings of Islam do maintain considerable vitality and appeal. That said, there is a compelling core of Islamic values for a rich understanding of peace that transcends the medieval legal constructs of war and peace, themselves not altogether devoid of departures from essential guidelines. Muslims are encouraged by the core teachings of their religion to deepen their commitment to equity and justice in a democratic and cosmopolitan manner.

A narrow preoccupation with Western hostility towards Islam has prevented Muslims from addressing local conflicts in the Middle East and elsewhere, and from taking advantage of increasingly democratic trends in their societies. Although radical fundamentalists like Osama bin Laden and Abu Bakr alBaghdadi have been content with a superficial appropriation of discredited symbols from earlier times (dar al-harb, dar al-Islam, belligerent jihad and revival of a caliphate), moderate revivalist thinkers have placed emphasis on the need for new ways of thinking about problems of domestic and international peace, as well as of global governance. ${ }^{1}$

Evidence shows that Islam has not been witness to any more violence than one finds in other civilisations, particularly that of the West, as manifested in colonialism, World War I \& II, the occupations and conflicts in Iraq, Afghanistan, Libya and elsewhere. Nonetheless, for the West it seems that events like the Muslim conquest of Spain and the Ottoman domination of Eastern Europe have provided a historical memory associating Islam with force and power. Moreover, the recent upheavals in the Middle East, and especially movements using the name of Islam and jihad for political ends, have reinforced the idea that, in some special way, Islam is related to violence. ${ }^{2}$ Certainly, mainstream Islamophobic propaganda readily endorses and magnifies this image. Nevertheless, it should be remembered that it has not always been valid. Indeed, and in an inversion of current events, Muslim countries were once where the persecuted of Europe, in particular the Jews, sought refuge. The pogroms and the inquisitions of Europe forced the Jews to migrate to both the Muslim countries of North Africa and the Ottoman territories. 
The Qur'an designates the Muslims as a community of the 'middle path' (ummatan wasatatan) which, together with its parallel concept of 'mutual recognition' (ta'aruf) for friendship, visualises Muslims as the agents and facilitators of peace. In the Muslim historical narrative, Islam is understood to have been a progressive, tolerant, and civilising force with binding rules constraining injustice and wanton violence. Islam's self-identity as a "religion of peace" is based on the premise that Islam challenges the root causes of human violence. Islamic scripture provides varied readings of warrior and pacifist perspectives. An attempt is made in the following pages to present a comprehensive vision of peace and the varied ways in which the source evidence of Islam is interpreted by its classical and contemporary commentators.

\section{Peace as a Theological Principle}

Islam's intimate identity with peace begins with its name: Islam (conventionally translated as "submission to the will of God") derives from the notion of salm, silm, and salamah, meaning security, peace-making, resignation and conciliation. It is also associated with the salam in the daily greeting of Muslims: as-salam alaykum 'may safety and peace abide with you.' It is an assurance of security and freedom from all harm. For Muslims, Islam suggests a state of peace and security that comes through renunciation of willfulness and rebellion. Sincere resignation to God's revealed guidance is the essential connotation of "Islam" and as a conventional term it serves as the name for the Muslim faith. "I have chosen Islam as your religion" (Q al-Ma'idah, 5:3).

Another important spiritual foundation for peace in Islam is the belief that God is Peace and is the ultimate source of Peace: "He is God; there is no god save He; the King; the Holy and the Peace (al-Salam)" (Q al-Hashr, 59:23). ${ }^{3}$ Symbolising the exalted name and attribute of God, peace in Islam thus partakes in a sparkle of the divine.

The five daily prayers (salah) that Muslims perform end with the salutation "peace be upon you," saluting first the right side of the world and then the left side of the world. Then also God's illustrious name, al-Salam, is recited in the supplication $\left(d u^{\prime} a\right)$ at the conclusion of the five daily prayers by Muslim worshippers: "O God, you are Peace, the source of Peace, and to you Peace returns, so help us live in peace ..."

Islam's notion of peace is holistic, implanted in the essence of human conscience and radiated into their hearts. This is then manifested into healthy thinking and positive attitudes, peaceful treatment of fellow men and women, the living inhabitants of the earth, as well as the flora and fauna of their natural surroundings. ${ }^{4}$ 
God shows His human servants the path to seek Him, and whoever sets out upon that path is rewarded with an inner tranquility (sakinah - Q al-Tawbah, 9:26 \& 40) that gives him strength to build a peaceful environment around him. Peace comes from God, but not in an obvious way, as the Qur'an says: "He it is Who sent down tranquility into the hearts of the believers... so that they might grow firm in their faith [in Him]" (al-Fath, 48:4). God then praises those who live peacefully with others in daily life: "The [true] servants of God are those who walk the earth with humility, and when the ignorant address them, they reply "Peace"" (al-Furqan, 25:63). Peace is thus to be found, not outside the heart of man, but primarily within it, and from here it spreads to the outer world. From the Qur'anic perspective, peace finds expression in three interlocking circles, the first of which is peace of the heart, which in turn nurtures peace with God and faith in Him, and which then extends to the third circle, peace with the outside world. All three circles interact and influence one another. ${ }^{5}$

Islam itself may not be imposed on anyone through compulsion and violence (Q 2:256). The Qur'an confirms that coerced religion would be pointless as it destroys the essence of conviction and belief. Muslims are enjoined to invite non-Muslims "to the Way of Thy Lord with wisdom and beautiful preaching; and argue with them in ways that are best and most gracious...God is with those who restrain themselves, and those who do good" (Q al-Nahl, 16:125-28). For Ibn Taymiyyah (d.1328 CE), the idea of initiating unprovoked war to convert people to Islam belies the religion: "If the unbeliever were to be killed unless he becomes a Muslim, such an action would constitute the greatest compulsion in religion." Ibn Taymiyyah's renowned disciple, Ibn Qayyim al-Jawziyyah, reiterated this point and wrote that "fighting is permitted on account of war, not on account of disbelief."

Paul Hedges wrote that "the freedom of religion that Europe developed around the period we called the Enlightenment actually came from an admiration of the tolerance seen in the Ottoman Empire." "The Ottomans had many religious traditions represented amongst their subjects and enacted policies to allow them to live together in relative harmony. The Ottoman Millet system sat at the heart of these policies. Applied to non-Muslim religious communities, this institution provided a means of accommodating religious diversity. Over centuries of expansion into non-Muslim lands, the application of the Millet system created an elaborate structure of fairly autonomous communities whose religious leaders were even able to develop formal relations with the rulers of other Muslim empires. ${ }^{9}$ In a manner unimaginable at the time, Christians, Jews, Sabeans, and Hindus all had access to considerably high state posts, right up until the dissolution of the Ottoman Empire at the beginning of the $20^{\text {th }}$ century..$^{10}$ "Europe had nothing like this, and so had to learn from it." ${ }^{11}$ Moreover, the Ottomans were 
not simply inventing this system, but were building upon foundations going back to the Prophet Muhammad and his early successors, the Four Rightly Guided Caliphs.

Compassion (rahmah) is another central concept in the Islamic order of values. God says in the Qur'an: "My mercy encompasses everything" (Q 7:156), and that "God has written mercy upon Himself" (Q al-An'am, 6:12, \& 54). Like compassion, peace cannot be imposed from outside. It starts within the hearts and minds of people and the dynamics it generates are externalised through patience, tolerance, generosity, and forgiveness. ${ }^{12}$

Ihsan (beauty and benevolence) is an integral part of the peace and spirituality of Islam. It is, however, possible to act rightly but be devoid of ihsan. One can practice the externalities of one's religion at the level of submission (islam) but be devoid of faith (iman). One can even be religious in both these senses (islam, iman) but be lacking in beauty and spiritual devotion (ihsan). The Qur'an repeatedly mentions God's love for the muhsinun, or those who practice ihsan, a state which is only possible when the existential reality of one's daily life is not overwhelmed by conflict. Peace thus becomes the prerequisite of beauty; it has theological significance, and it partakes in the comprehensive fulfillment of Islam.

\section{Peace Through Inclusivity and Universalism}

Tawhid, the principle of Divine Oneness, is the first article of the Muslim faith and a major theme of the Qur'an. There is only one God and essentially only one humanity too, which implies that all humans are equal, simply because we are all of one and the same essence and ancestry. "O mankind!" God says in the Qur'an, "surely We have created you from a male and a female and made you into tribes and nations so that you may get to know each other. The noblest of you with God are the most righteous of you" (Q al-Hujurat, 49:13). The Qur'an also appeals to the people to cooperate in good deeds and "cooperate not in hostility and sin" (Q al-Ma'idah, 5:2), and then it also enjoins them to: "vie with one another in good works. For to God you shall all return..." (Q al-Ma'idah, 5:48). Tawhid thus constitutes the basis of Islam's universalism, inclusivity and tolerance.

The universalist outlook of tawhid is also manifested with reference to the sanctity of human life. Every human life is equally important, without discrimination of any kind. God has repeatedly proclaimed that human life - a sacred gift - may never be taken without a "just cause." Islam protects every life and therefore seeks to establish safety and security for all.

In the Sufi tradition, tawhid has meant, not only the unity of God, but also the presence of God within His creation and the complete dependence of creation 
upon its divine foundation - a condition some Sufi metaphysicists have described as "the unity of being" (wahdat al-wujud). By offering an "inner Islam" for those seeking a path to God, Sufism has left a profound mark on Islamic culture. By expressing itself in literature, philosophy, music, poetry, ethics and the visual arts, Sufism has created a culture in which love is "presented as the key to Islamic life and practice." 13

Despite its emphasis on tawhid, however, the Qur'an is also cognisant of internal diversity and pluralism among human communities and nations, whether on account of language, creed, custom or culture: ${ }^{14}$

Unto each of you We have appointed a [different] law and way of life. And if God had so willed, He could surely have made you all one single community. But [He willed it otherwise] in order to test by means of what He has vouchsafed unto you. Vie, then, with one another in doing good works! (Q al-Ma'idah, 5:48; and Q Hud, 11:118).

The existence of tawhid in a pluralist world implies the need to discover through dialogue that which is common and universal in all religions and pursue them through respectful debate and cooperation. Advocates of peace through universalism therefore seek to engage with representatives of different cultures and religions on the basis of this Qur'anic principle of divinely-sanctioned pluralism in human societies. Human diversity exists as a function of divine will and not because of human proclivity alone. In light of this diversity, exchanges of views about the world's many pressing problems ought to be conducted in a way that not only reflects Islamic values but also calls on others to act on the guidance they have received. It also means strengthening the institutions of international law and bolstering a global civil society of world opinion in order to promote and protect peace and justice. ${ }^{15}$

Authoritative voices among Muslims who embrace the Sufi dimension of Islam have often called for respectful communication among all of the world's religions, including Hinduism, Buddhism, Taoism and Confucianism. Prominent Muslim scholars, including Seyyid Hossein Nasr and Abdul Aziz Said, maintain that Islam offers a confident but not overbearing perspective on human religious experience. Islam retains its core theological claim with respect to the principle of divine unity while supporting dialogue among spiritual practitioners on a basis of appreciation and mutuality. ${ }^{16}$

The absence of a central religious authority or clergy in the Islamic tradition preempts authoritarianism as a model, and as further attested by the multiplicity of schools of Islamic theology and law. The incremental process of establishing orthodoxy is not therefore the monopoly of the ulama; it is shaped by a multitude of social agents, including men of letters, political leaders, artists, scientists, 
traders and theologians. The dissemination of religious authority on the one hand, and the malleability of cultural expressions in Muslim societies on the other, have challenged authoritarianism and also raised questions of legitimacy and authenticity.

In creating their cultural orthopraxis, Muslim communities have used the ethical universalism of the Qur'an and Sunnah, especially the Qur'anic call to enjoin what is good and praiseworthy ( $\mathrm{ma}^{\prime} \mathrm{ruf}$ ) and reject what is morally evil and disliked (munkar). This non-culture-specific injunction was addressed to all people, regardless of their religious affiliations. The notion of the middle community (ummah wasatah, Q 2:143) supports the same ethical universalism: "And thus We willed you to be a community of the middle way, so that you might bear witness to the truth before all mankind, and that the Messenger might be a witness over yourselves."

This ethico-spiritual universalism aims to create an open society based on moral values, not on the received traditions of one tribe, city or nation. The fact that the Qur'an positions itself against the cultural and tribal localism of preIslamic Arabia confirms this universalistic outlook. ${ }^{17}$ Instead, society should be based on knowledge ('ilm) and moral virtue (taqwa) (Q 49:13). These are the ultimate criteria of nobility, before both God and humanity. In this milieu, cultural and religious co-existence is not based on the mere temporary absence of conflict and confrontation between Muslims and non-Muslims; it is about Muslims' inclusive attitude toward other cultures and religions, making Islamic civilisation, as Hodgson phrased it, "simultaneously both Islamic and islamicate."18

The experience of conveviencia among Jews, Christians and Muslims in Andalus was a result of the Islamic notion of cultural inclusivism. While the Jews of Europe were subjected to woeful vilifications during the Middle Ages, a major Jewish intellectual tradition developed under Muslim rule and included prominent figures of medieval Jewish thought. This resulted in a unique interaction between medieval Jewish philosophy on the one hand and Islamic philosophy, kalam, and Sufism on the other. ${ }^{19}$

During the ninth and tenth centuries CE, Baghdad, the Abbasid Empire's capital, became one of the most cosmopolitan cities of the medieval world, where Muslim, Jewish and Christian scholars collaboratively searched for knowledge. Along with Cordoba in Andalusia, Baghdad was one of the two focal points of a remarkable research programme: the collection, translation and synthesis of all known sources of human knowledge. Not only Greek but also Indian, Iranian and Chinese advances in knowledge were integrated into this synthesis. Syriac Christian and Jewish scholars played a particularly vital role in an officially sponsored effort to translate scientific and philosophical texts into Arabic. ${ }^{20}$ 
A little later, the Indian subcontinent saw a cultural syncretism develop between Hindu and Muslim cultures, as evinced by Abu Rayhan al-Biruni's (d.1047 CE) historic study of India and Amir Khusraw's (d.1325 CE) formulation of an Islamic identity in the Indian cultural environment. A vast literature came into being as a result, generating a unique symbiosis between the two worlds at the social, philosophical, artistic and cultural levels..$^{21}$ Such modes of inclusivity and coexistence were made possible by the Qur'anic recognition of diversity and mutual recognition.

Even though Muslim fundamentalists consider cases of cultural symbiosis and syncretism to be deviations from their idealised construct of Islam, traditionally both the Islamic intellectual tradition and Muslim societies have envisaged peace as a cross-cultural and intercommunal value that overrides and subsumes isolated and sectarian readings of Islamic heritage and scripture. ${ }^{22}$

Sufism provides a powerful outlook on inclusivity and universalism. It opens a window to the inner world of spirituality, linking peace in the world to internal processes of human transformation. A Sufi approach to spirituality represents Islam's capacity for fostering inclusiveness and an appreciation of human differences. According to this universalistic Islamic perspective, cultural and religious diversity becomes a resource for humanity's enrichment.

Although the Sufis did not create a separate sect within Islam, they were united by an ambitious understanding of the spiritual paths of their religion. They aspired not so much to attain a heavenly reward in the afterlife, as to 'meet' God in life through a deep commitment to doing what is beautiful in daily activities and observances. ${ }^{23}$ Even today, Sufism transcends sectarian identities and represents an aspect of Islam whose core doctrines are shared by both Sunni and Shia. The broadminded ecumenical and universalist tendencies within Sufism have endowed the present generation of Muslims with a rich heritage that can be used to build bridges of cross-cultural and interreligious understanding in the modern world.

\section{Peace Through non-Violence}

In a conflict-ridden world, those who wish to see a radically different culture embodying the values of justice, love and mercy ought to take the way of peaceful resistance since radical and lasting change can only spring from the transformed hearts of human beings. Mahatma Gandhi, who was no armchair theorist, but a militant political leader facing the might of British imperial power, said that nonviolence comes from strength, and the strength is from God, not man. Seeking peace through non-violence always comes from within. ${ }^{24}$

A survey of the Qur'an reveals not only passages that grant legitimacy to armed resistance to oppression, but also ones that reject wanton bloodshed 
and the use of force for aggressive purposes. Like the Torah and the Bible, the Qur'an identifies Cain's offence against Abel as the first instance of violence in human history, clearly marking it as a great wrong through which Cain became responsible, not only for his own sins, but also for those of his brother. Abel confronts Cain before the latter's fateful action, and tells him: "Even if you stretch out your hand against me to kill me, I shall not stretch out my hand against you to kill you. I fear God the Lord of the worlds" (Q al-Ma'idah, 5:28). From this vantage point, the Qur'an asserts in a passage reminiscent of one in the Jewish Talmud a moral imperative to protect life: "On that account, We decreed for the children of Israel that if anyone slew a person - unless it be for murder or for spreading mischief upon earth - it would be as if he slew all humanity." The passage then continues: "and whoever saves a life, it would be as if he saves the life of the whole of humanity" (Q al-Ma'idah, 5:32). Other Qur'anic passages exemplifying peace through non-violence include:

Whenever they [mischief-makers] kindle the fire of war, God extinguishes it. They strive to create disorder on earth and God loves not those who create disorder. (Q al-Ma'idah, 5:64)

God commands you to treat [everyone] justly and kindly. (Q An-Nahl, 16:90)

Good and evil can never be equal. Repel evil [not with evil but] with good, then you will see that even one with whom you had enmity will become as though he were an intimate friend. (Q Fussilat, 41:34)

Fear God, and know that God is with those who restrain themselves. (Q al-Baqarah, 2:194)

The Prophet Muhammad added his voice to this in several hadiths:

Gentleness fails not to create beauty whenever it enters into something, and it is not taken away from anything without causing ugliness.

A Muslim is one from whose hands and tongue other Muslims [read human beings] are safe.

People are God's children, the most beloved of them to God is one who is of greatest benefit to his children.

Muslims are enjoined never to give up hope that peace will prevail. "It may be that God will bring love (and friendship) between you and some of those whom you (now) hold as enemies. For God has power over all things. He is most 
forgiving, most merciful" (Q al-Mumtahanah, 60:7). Muslims are enjoined to be just and kind to all their fellow humans regardless of their colour and creed - if they have not been aggressive toward them [Muslims] nor invaded their homes (Q 60:8).

The scriptural sources of Islam are emphatic about the merits of patience (sabr), which is widely seen as a manifestation of quietist yet activist resistance to the wrongdoings and excessive behaviour of others. The Qur'an ( $\mathrm{Q}$ al-Zumar, 39:10) promises that "Those who are patient will be given their reward without measure." This is endorsed in another verse which says "They will be awarded in the high place [in heaven] for what they bore in patience." (al-Furqan, 25:75). And again: "As for those who after persecution fled their homes and strove actively and were patient to the last, your Lord will be forgiving and merciful to them" (16:110). The Prophet began his ministry in Mecca with non-violent resistance to persecution and persistent provocations by the Quraysh of Mecca. He remained steadfast in this for 13 years until his migration to Madinah, which marked the momentous event of the Hijrah, itself a vivid manifestation of nonviolent and patient (yet activist) resistance to aggression. ${ }^{25}$ In a long hadith, the Prophet is reported to have said: "Patience is of three kinds: patience during tribulations, patience in obedience to God, and patience in avoiding sin. Whoever remains patient during a tribulation until he averts it, God will ordain for him three hundred levels [of recompense]..."26

Ibn Abi al-Dunya's (d.894 CE) treatise on the virtues of patience (fada' $i l$ al-sabr) underscores patience as a hallmark of piety. According to a hadith report by one Abu Imran al-Juni, "After faith, the believer has not been given anything more meritorious ( $a f d a l$ ) than patience with the exception of gratitude, but it [patience] is more meritorious of the two and the fastest of the two to reap recompense for the believer." ${ }^{27}$ A similar report by the ninth century scholar, Sufyan b 'Uyaynah (d.813 CE), says: "The believers (al-abad) have not been given anything better or more meritorious than patience, by means of which they enter heaven." ${ }^{28}$

Religion must be taught in a civil, non-violent, and courteous manner - as the Qur'an enjoins the Prophet, "You are not one to overawe them by force ( $b i$ jabbaar)" (Qaaf, 50:45). A Muslim's attitude towards the 'other' should be: "To you is your religion and to me my religion." (al-Kafirun, 109:6). These verses merely endorse the basic Qur'anic position that "There shall be no compulsion in religion" (2:256).

Due to the sacredness of human life, non-violence becomes of primary importance for Muslims when resolving conflicts. Several Muslim leaders have spearheaded the peace-through-nonviolence initiative, including Badiuzzaman Said Nursi (1876-1960), Abdul Ghafar Khan (also known as 'Frontier Gandhi' 
1890-1988), Lala Aziza, Ghazal al-Magdashiyyah, and Fethullah Gulen. Other significant advocates of non-violence include Mubarak Awad, Chiawat SataAnand, Hakim Mohammad Said, Sakina Yakoobi, and Jawdat Sa'id. ${ }^{29}$ The Qur'an inspired most of these in their advocacy for non-violence, each quoting passages from the Qur'an in support of their views.

For example, in his magum opus, the 6,000-page Risalae-i Nur, Nursi developed the principles of the non-violent actions of love, tolerance, and good reason. There is a profound focus in Nursi's work on responding to evil with understanding and kindness, to working for peace regardless of the obstacles and unfavourable conditions. He firmly believed that responding to evil with evil would create a vicious cycle and only increase the spread of evil. ${ }^{30}$ On the subject of jihad, Nursi wrote that "spiritual jihad is the jihad of this century." His understanding of jihad involved preventive action through communication and dialogue. This was because violence in society would contravene the rights of innocent people. Acting in an ethical and positive way - taming anger and revenge - would protect the lives of others. ${ }^{31}$

Nursi wrote that "Hatred should only be directed to ignorance, poverty and hypocrisy," and that "our relations with non-Muslims will be in the way of persuasion. It is our duty to present Islam to them as a religion of love." For Nursi, non-violence was an integral part of Islam, and he argued that the future of civilisation depends on peaceful co-existence. ${ }^{32}$

Nursi lamented the atrocities of the two World Wars and wrote that when the human heart is shorn of respect and compassion, rationality cannot tame mankind's animal self. Equally, when driven by greed and selfishness, human beings can turn into "cruel and horrible monsters." Nursi frequently quoted the Qur'anic directive for Muslims to "make peace among your brethren" (alHujurat, 49:10) and its guidance that one should respond with "what is most beautiful," so that "the one with whom you had enmity could become an intimate friend" (Fussilat, 41: 34). ${ }^{33}$

Today, Nursi's message is most notably carried forward by Fethullah Gulen, who has, like Nursi, inspired millions to work for peace through service, including the establishment of schools, charities, media outlets, and youth groups around the world, whether for Muslims or non-Muslims. Through these efforts, Gulen has been contributing extensively to global peace efforts in many countries. ${ }^{34}$

Turning to Abdul Khafar Khan, he founded the Afghan-Pashtun Khuda'i Khidmatgarspeace movement. By doing so, he established the world's first nonviolent army using the Islamic principles of patience, kindness and love, as well as the Pashtun traditions of honour, bravery and commitment to one's word. He mobilised the frontier province of the Indian subcontinent during British colonialism to protest oppression and occupation. ${ }^{35}$ Using the Islamic values 
of service through action ('amal), faith (yaqeen) and love (muhabat), Khan argued that the connection between Islam and peacebuilding is more obvious and stronger than the stereotypical link to violence. He maintained that Islam emphasises social justice, brotherhood and equality of mankind. ${ }^{36}$

Ghazal Ahmad 'Alwan al-Magdashiyyah, of late $19^{\text {th }}$ century Yemen, was a powerful and persuasive dispute mediator who successfully resolved a number of conflicts through non-violent means. In due recognition of her role, her name was given to the main lecture hall at the Empirical Research and Women's Studies Center at the University of Sanaa. ${ }^{37}$

In the context of the Arab-Israeli conflict, Mubarak Awad has striven to promote religious values and ethical considerations in order to persuade the warring groups to explore non-violent coexistence. Although these efforts have yet to bear fruit, in several places their presence is considerable. ${ }^{38}$

Moroccans have long recited the narrative of Lala Aziza, a courageous and deeply spiritual Muslim woman of the fourteenth century C.E, who reconciled conflicting tribal groups and, on one occasion, persuaded the governor of Marakesh to desist from acts of military aggression against the people of her region. According to traditional lore, she approached the general and his army when they reached the region of Seksewa, where she lived. Her face-to-face debate with the general was entirely couched in Islamic discourse. Unsettled by the woman's courage and personal charisma, the general gave up his ambition to subjugate her people. ${ }^{39}$

In addition to these specific examples, the Sufi tradition has also traditionally embodied a spirit of non-violent protest. During the Abbasid and Ottoman periods, for example, numerous Sunni and Shia Sufi leaders refused to sanction calls to military jihad by rulers whom they deemed to be unjust. ${ }^{40}$

\section{What of jihad?}

References to jihad in the Qur'an occur in twenty-four verses, most of which advance a spiritual and non-violent understanding thereof concerned mainly with: being steadfast in faith and being prepared to make sacrifices in its cause; with the migration of the nascent Muslim community from Mecca to Madinah; with the peaceful propagation of Islam, and with personal and financial sacrifice. ${ }^{41}$

Jihad in the sense of self-discipline, or jihad al-nafs, for example, is repeatedly mentioned in the Qur'an:

And whoever strives (jahada), he only strives for his own self, for God is independent of his creatures (Q al-'Ankabut, 29:6).

As for those who strive for Us (jahadu fina), We surely guide them to Our paths (Q al-'Ankabut, 29:69). 
Obey not the unbelievers, but strive against them with it (jahidhum bihi) with utmost striving (jihadan kabiraa) (Q al-Furqan, 25:59).

The renowned Companion, Ibn 'Abbas, commented that the phrase 'strive with the utmost striving' in the last verse denotes preaching and exhortation as the greatest forms of jihad, and that 'with it' refers to the Qur'an itself. ${ }^{42}$ It should be noted that none of these references to jihad have a military connotation; they are references to the jihad of enlightenment and education, as guided by the Qur'an itself.

According to a Hadith: "The mujahid is he who wages a struggle against himself." ${ }^{3}$ And then again that "The best form of jihad is to tell a word of truth (kalimatu haqqin) to a tyrannical ruler." ${ }^{44}$ 'Jihad against the self' is the foundation of all jihad, for fighting an external enemy would not be possible without a successful engagement in this inner jihad. In this respect, the Sufis have taken this Hadith as the main authority for their doctrines. ${ }^{45}$

In a Hadith record by al-Bukhari (d.870 CE) and Muslim (d.875 CE), a young man asked the Prophet: "Should I join the jihad?" In response, the Prophet asked him a question "Do you have parents?" and when the man said "Yes", the Prophet told him "then strive by serving them." "46 Likewise, al-Bukhari and Muslim both record another hadith, stating that "One who helps widows and the poor are like fighters in the path of God." ${ }^{47}$ According to another hadith, recorded by Ahmad ibn Hanbal (d.855 CE) and al-Tirmidhi (d.892 CE), "One who strives against oneself is a mujahid who carries out jihad." 48 The Prophet has also said: "Whoever goes out in the world seeking licit work to support his family is in the path of God; whoever goes out in the world seeking licit work to support himself, is in the path of God." ${ }^{\prime 49}$ Al-Tirmidhi has recorded the following hadith: "Whoever departs in pursuit of knowledge is in the path of God ( $f$ sabil Allah) until he returns." ${ }^{50}$ This clearly rebuts the assertion by some that the phrase " $f i$ sabil Allah" refers to military combat only.

The Andalusian jurist and theologian Ibn Hazm (d.1064 CE) held that defending Islam through non-militant, verbal and scholarly efforts qualified as a meritorious struggle in the path of God. Jihad is best carried out, he affirmed, through inviting people to God by means of the tongue and through defending Islam by sound opinion. By contrast, armed combat was marginal as, Ibn Hazm added, the majority of the Prophet's activities fell into nonviolent categories. ${ }^{51}$

Given the above, the common usage of jihad appears to be peaceful. This is especially so in the Qur'an's early Meccan revelations. During the initial thirteen years of the Prophet's ministry in Mecca, he conducted his mission entirely through non-violent means, even to the extent of not allowing his followers to defend 
themselves against aggression. When, for example, the Meccans persecuted the Muslims and forced a number of them to migrate, initially to Abyssinia and then later to Madinah, some of them urged the Prophet to allow a reciprocal response. He repeatedly refused, however, due to Qur'anic injunctions like:

So wait patiently (O Muhammad) for thy Lord's decree, surely thou art in Our sight (al-Tur, 52:48);

Then bear with them and say: peace. They will (eventually) come to know (al-Zukhruf, 43:89).

So overlook (any human faults), with gracious forgiveness (al-Hijr, 15:85);

Repel (evil) with what is better, and when you do that, the one with whom you had enmity will become your dearest friend (Fussilat, 41:34).

Even when the pagans of Mecca planned an attack on the Prophet's life, he chose to migrate to Madinah rather than retaliate. Only a year later, when the Meccans set out to attack the Muslim community in Madinah, was the first Qur'anic verse permitting fighting revealed:

Permission is granted to those who fight because they have been wronged, and God is indeed able to give them victory; those who were driven from their homes unjustly because they said: our Lord is God (al-Naba', 78:39).

So, whereas in Mecca Qur'anic references to jihad were all to its peaceful manifestations, in Madinah references to jihad began to include military jihad (cf., Q 2:215; 9:41; 49:15). But these passages validated jihad in the sense of a 'just war' fought to repel:

And fight in the way of God those who wage war on you, but do not transgress, for God loves not the transgressors (2:190).

Thus it is clear that military jihad is waged in self-defence and against aggression. By contrast, jihad as an offensive war does not have any scriptural mandate. Rather, it is a latent development that features in the work of those jurists and commentators who sought to legitimise the policies of territorial expansion. ${ }^{52}$ When planning to mobilise the military for purposes of annexation or conquest, especially at times when no organised armies existed, Muslim rulers would encourage religious leaders to declare jihad to legitimise attack. This was the case, for example, when Amir Abur Rahman of Afghanistan waged a jihad against Nuristan in 1895; before the attack, he convened a large number of religious figures to issue a collective fatwa in support of it. ${ }^{53}$ 
The peaceful objectives of jihad and a respect for freedom of religion can be seen in the renowned Constitution of Madinah, dating back to the first year of the hijra/622 CE. This document guaranteed freedom of religion for non-Muslims, Jews and Christians. The same sentiment is noted in a renowned letter by the first Caliph Abu Bakr, dated $12 \mathrm{AH} / 635 \mathrm{CE}$, that exhorted the Muslim troops leaving for a Syrian campaign to protect civilian life and property and avoid torture and undignified treatment of prisoners of war. Written at such an early point of Islamic history, it is remarkable to note how closely Abu Bakr's letter resonates with the spirit of contemporary international law. Respect for freedom of religion is also manifested in the second Caliph, Umar al-Khattab's, example following the defeat of the Romans at the Battle of Yarmouk in $648 \mathrm{CE}$. The caliph made a pledge on behalf of all Muslims to protect the places of worship of Jews and Christians and allow them unhindered freedom of access to their churches and synagogues. ${ }^{54}$

Muhammad Abu Zahrah (d.1974 CE) has quoted Taqi al-Din ibn Taymiyyah (d.1328 CE) in support of his own conclusion that war in Islam is permitted for only one purpose: defence against aggression. This is why the permission to fight granted by the Qur'an to Muslims is immediately qualified by the phrase "and do not transgress". ${ }^{55}$ The ultimate goal of war in Islam is to prevent fitnah (sedition, tumult), as in the verse: "And fight them until fitnah is exterminated" (Q al-Anfal, $8: 39)$.

Influenced by the prevailing pattern of hostile relations with non-Muslims, some Muslim jurists took an extreme position on the subject of abrogation (naskh) in the Qur' an. The so-called verse of the sword (ayat al-sayf, 9:5) was thus taken to abrogate no less than 114 (and according to some, 140) verses on peaceful relations with non-Muslims spread across 54 suras of the Qur'an. The verse in question was revealed when the Prophet negotiated the truce of Hudaybiyah with the pagan Quraysh. A year later, the Quraysh violated the terms of that treaty, and it was on this occasion that the verse in question was revealed, addressing Muslims to "Slay those who ascribe divinity to others than God wherever you find them, and take them captive and besiege them." The text then states that, if the enemy repents and mend its ways, violence must be brought to an end (Q al-Tawbah, 9:5). I shall not engage with the details of abrogation, which I have treated elsewhere, ${ }^{56}$ but suffice to say that it is a controversial subject and that to use it in order to establish such a drastic position as abrogating a whole chunk of the Qur'an on peaceful relations, justice and tolerance, patience and perseverance, treating others with fairness and dignity, is far too excessive. The verse is also taken out of its particular context and exceedingly generalised.

In course of time, juristic writings on jihad became so preoccupied with the military aspects of the term that it began to be used only in that sense, to the 
near-total exclusion of its wider connotations. Western militarism and violence during and after colonialism exacerbated the situation; against the background of the West's anti-Islamic policies and onslaught, the Muslims began to strike back and became more inclined to embrace the militaristic interpretations of jihad. The persistent Western media depictions of Muslims as prone to terrorism and violence, however, calls for a corrective. The fact is, and as Mazrui notes, that "in the last 100 years Western civilisation has killed millions more people than any other way of life in the annals of man in a comparable unit of time.... It has also been the West in the preceding 100 years which had made warfare less and less respectful of civilians." ${ }^{57}$ The Christian ethic of the minimisation of violence has been observed more by non-Christians in Asia and Africa and elsewhere than by ostensible followers of the Cross. ${ }^{58}$

\section{Peace Through Equity}

In contrast to 'peace through subjugation,' wherein peace is understood in conceptually minimalist terms as the absence of war, 'peace through equity' conceives of peace as the presence of justice, communal self-determination and solidarity. Certainly, peace cannot be truly said to exist in the face of persistent injustice. Efforts to promote equity and justice thus qualify as a form of jihad. Islam itself may be described as an uprising for justice providing guidelines for establishing a just and humane society. The Muslim Ummah can also play a significant role in peace-making by acting on the Qur'anic principle of "enjoining what is right and forbidding what is wrong." 59

In its affirmative sense, Islam's version of peace through equity is concerned with social justice, necessitating the elimination of extreme disparities in society. Social justice envisages a fair distribution of wealth and opportunity, of the prevention of large gaps between rich and poor. The existence of large disparities, however, has become a stark feature of the twenty-first century and is a source of tension, both within Muslim societies and in the larger context of global relations. Islamic teachings regard the existence of economic deprivation as a social wrong caused by the failure of society and state to protect the weak. The imbalances are often caused by hoarding, protectionist trading policies and unfair exploitation. Insofar as poverty and economic exploitation lead to social turmoil, the objectives of security and economic justice are naturally threatened and compromised. Islam is emphatic on care for the poor and the deprived, and sees economic justice as a means toward a state of equilibrium and social peace. ${ }^{60}$

Islamic explanations of disequilibrium and injustice in human societies emphasise an indictment of greed, moral blindness and egotism, be it individual or collective. The worst forms of human oppression are derived from tyranny 
of the human ego, referred to in the Qur'an as taghut, a well-spring of moral transgression that ultimately partakes in idolatry (shirk). For many Islamic ethicists, idolatry manifests not only in the theologically erroneous attribution of partners to God, but also in humanity's existential attitudes of egotism and greed.

The contemporary Islamic call for justice critiques exploitative capitalism, assertive nationalisms that override consideration of equity and fair treatment of others, racism and fanatical tribalism. Whereas power politics utilise double standards that sow seeds of oppression and discontent, Islam's peace through equity perspective evokes a common ethical standard of universal appeal. The purpose of politics should be to advance the cause of justice, rather than merely preserve the status quo or pursue the benefits of only one particular state, nation, or subnational group. ${ }^{61}$

Islam subscribes to an essentially optimistic view of human nature (fitrah) and potential, which is in turn the basis of humankind's vicegerency (khilafah) in the earth, or the divine trust to build the earth up with peace and justice. The 'peace through equity' approach also recognises that coercion and violence cannot persuade people to act justly, and that achieving positive ends for world peace requires skilful persuasion and advocacy of shared moral standards. Only approaches that are deeply rooted in moral and humanitarian values can provide a basis for sustainable peace.

\section{Peace Through Conciliation}

The Qur'an repeatedly enjoins Muslims to, whenever possible, respond to provocations with patience and affirmative action capable of facilitating conciliation. Fighting should be avoided until it becomes necessary - that is, after all attempts have failed to achieve a peaceful resolution. This approach is not vastly different from the Western notion of a Just War, which also considers war to be the last resort. Peace through conciliation and the restoration of harmony remains God's preference and a higher objective of Islamic theology and law. ${ }^{62}$

From an Islamic viewpoint, the prevalence in Western thought of individualistic rationality and self-interest is lop-sided and problematic. Contemporary Western thinkers place a high premium on the skilful management of competition and conflict through an international system based on exploitative capitalism and a balance of power. Islamic thought argues in normative terms for a world order that cannot be constructed without commitment to justice, security and peace. ${ }^{63}$

That said, neither the West nor Islam is monolithic and both face noticeable tensions between professed and actualised commitments. The age of globalisation dictates that both must aspire to an enlightened global citizenship. Listening to different cultural voices - and those of the Muslims in particular - is all the more 
important for the West, both so that it can know itself better and coexist with others in an ever-shrinking world.

At the level of linkages between precept and practice, Islam provides multiple approaches to the peaceful resolution of conflicts, many of which have parallels in other traditions and cultures. Yet partly due to media bias, but also radicalism and militancy in the name of religion, inquiry into the precepts and practices of peace in Islam is still a relatively new topic for modern scholarship. Nonetheless, interest in the alternative methods of dispute resolution in Islamic law has grown wider in recent decades, beyond its traditional and relatively narrow focus of Islamic banking and finance. The following paragraphs look at Islamic approaches to conflict resolution through negotiated settlement (sulh), arbitration (tahkim), grant of amnesty and forgiveness ('afwa), counselling (nasihah), and truce (al-hudnah) to allow time for settlement. These are in addition, of course, to adjudication ( $q a d a$ ), which is of concern mainly to courtroom proceedings that, although well-regulated, are also protracted and restrictive, often lacking the flexibility offered by the non-courtroom alternative methods. We shall therefore preclude adjudication from our coverage and suffice by saying that it is available in most cases of concern here, as a last resort. The disputing party or parties may thus opt for adjudication if the alternative conflict resolution methods have failed to deliver the desired results.

\section{Dispute Settlement Through Conciliation (Sulh, also Islah)}

In this method, individual parties agree to settle a dispute among themselves without the involvement of a third party. The linguistic meaning of 'sulh' is to end a dispute through conciliation and agreement reached via a variety of tools, including negotiation, mediation, reconciliation, and amicable settlement through compromise. However, from the legal viewpoint sulh is a contract which needs to be ratified by the expressed agreement and consent of disputing parties who are, in principle, attempting to end the dispute between them. Without wishing to enter into details, Muslim jurists have elaborated on the juristic consequences of the contract of sulh, adding a number of other contract varieties that may be integrated therein, depending on whether the terms of sulh involves exchange of values, waivers, affirmation or denials of statements, and so forth. The Qur'anic authority for sulh is provided in the following passage:

In most of their secret talks, there is no good, but if one enjoins an act of charity or justice, or conciliation between people (islah bayn al-naas) [then secrecy is permissible], and those who do this earn God's pleasure and the highest reward. (Q al-Nisa', 4:114) 
Ibn Rushd al-Qurtubi (d.1126 CE) comments that this verse is a general ('am) statement on conciliation and applies to all disputes pertaining to life, property and honour - indeed, to any claim or disagreement that gives rise to a dispute among people. ${ }^{64}$

Elsewhere the Qur'an speaks of conflicts that may arise between two Muslim groups. In these cases, an attempt must to be made to reconcile them ( $f a$-slihu baynahuma). But, if any such attempt fails due to, for example, one party's aggression and lawlessness, then the aggressors should be fought until they cease aggression. If they cease aggression then "make peace between them with justice - fa-slihu banahuma bi'l- 'adl." The verse then continues: "the Believers are but a single Brotherhood. So make peace between your two [contending] brothers." (al-Hujurat, 49:9).

In a separate passage relating to disagreement and discord between spouses, the Qur'an enjoins them to settle their differences amicably, for "conciliation (al-sulh) is best" (al-Nisa', 4:128). The text therefore not only permits sulh, but recommends it as the best way to resolve matrimonial conflicts. This is said without any qualification, as priority is given to unqualified reconciliation, rather than one contingent on justice. In other places the text usually espouses peace with justice, especially when conflict has led to military confrontation and violence.

A question has arisen about whether a one-sided and unjust peace should be rejected and abandoned, or whether it is still permissible. Two responses have been given to this question. First, it has been noted that the Qur'an has praised peace-making absolutely. As such, we do not necessarily need to look at the fairness aspect of an agreement, as sulh is not always an issue of legality and rectitude, but of putting an end to hostility and violence. To support this view, proponents point to the hadith in which the Prophet says "Peace among Muslims is permissible - al-sulh ja'iz bayn al-Muslimin." Turning to the second view, this refers to some of the qualifications that the Qur'an itself (and also some hadith) have recorded - namely, the stipulation that sulh may not turn what is halal into what is haram, and vice versa. For example, in a hadith narrated by Abu Hurairah, the Prophet said: "Making a settlement between Muslims is permitted, except that which permits what is prohibited or prohibits what is permitted." 65 Juristic discussion records further details on this but draws the conclusion that permissibility of peace generally is the preferred position. ${ }^{66}$ Scholars of hadith and fiqh have further held that the substance of these provisions applies to Muslims and non-Muslims alike, unless the position has been specified otherwise.

That all this is mentioned as occurring 'between Muslims' merely reflects the fact that they are the ones most likely to adhere to Shariah judgments. Certainly, Islamic law recognises several types of settlement based on the relationship of the parties involved, and each type is treated individually. These 
include settlements between a Muslim state and a non-Muslim state; between the head of state (Imam), rebels and renegades; between husband and wife; and between parties to a financial dispute etc., which we do not propose to elaborate on here. ${ }^{67}$

Sulh is also a private dispute settlement method, appropriate for disputes in which the parties concerned agree upon a solution without involving any courtroom proceedings. The parties may also agree to refer the matter to a community appointed judge, who may enjoy broad support. In this respect, sulh may be suitable for Muslim minority groups living in non-Muslim majority countries, who may find themselves operating within multiple laws and judicial systems, especially in personal law matters, such as family and inheritance disputes. The parties may consequently agree voluntarily to resort to a private sulh settlement method. ${ }^{68}$ But sulh may also be suggested by the court: the judge may ask the parties to negotiate and reach a settlement through mutual agreement between themselves, thus avoiding adversarial court litigation. On this note, the second caliph, 'Umar ibn al-Khattab, is quoted as having said: "refer the litigants to attempt conciliation (sulh) between them, for court adjudication often leaves the parties with unsettled resentment. ${ }^{96}$

\section{Arbitration (Tahkim)}

Tahkim is voluntary arbitration in which disputing parties appoint an arbitrator to resolve their dispute. The linguistic and juridical meanings of tahkim are almost concurrent - to designate someone as an arbitrator/judge when deciding on a given matter. The difference between arbitration and courtroom proceedings, however, is that, in the former, the parties themselves select the arbitrator and voluntarily accept to obey his or her decision. The parties may also stipulate conditions to their agreement - for instance, regarding time limits, the place of arbitration, or that a certain learned person or body be consulted/involved etc. ${ }^{70}$ Arbitration is a lesser form of dispute resolution, inasmuch as it is undertaken pursuant to private authority, whereas adjudication by the court of law partakes in the exercise of public authority. ${ }^{71}$

All the leading schools of Islamic law uphold the validity of arbitration, although most tend to preclude crimes and punishments and the decisive injunctions of Shariah, such as the prescribed penalties (hudud) and just retaliation (qisas). The Hanbali school has, however, removed all such limits and offers the widest scope for arbitration, holding that it applies to all disputes and litigations that can be adjudicated before the court of justice, including financial matters, matrimonial disputes, crimes and penalties, hudud and qisas. ${ }^{72}$

Arbitration must fulfill the following conditions: 1) The arbitrator is a competent person. For the Hanafi School, this means that he/she is qualified to 
be a judge. The Shafi'i, Maliki and Hanbali schools, however, do not specify this as a requirement. In the context of this condition, it is further stated that, if both parties are Muslim, the arbitrator should also be a Muslim, but a non-Muslim may be appointed as arbitrator if both or one of the parties to the disputes is nonMuslim; 2) There is a real conflict to be resolved; 3) The parties agree to accept the result of the arbitration. In the event that the local court or qadi appoints the arbitrator/s, however, the parties' advance consent to the outcome of arbitration is not necessary. The Hanafi school also validates arbitration even if the parties' consent is given only after the arbitrators' decision is announced; 4) That the arbitrator is not related to one of the parties such that it would be prohibited for one to be witness for the other (like parent and spouse).$^{73}$

Textual authority for arbitration is provided by both the Qur'an and Sunnah. In the Qur' an, God Most High says with reference to matrimonial discords: "And if you fear a breach between them [the spouses] appoint an arbitrator from his folk and an arbitrator from her folk. If they both desire reconciliation" (al-Nisa', 4:35). In a subsequent verse in the same chapter, it is provided with reference to the Prophet that: "They can have no (real) faith until they make [you] the arbitrator/judge (yuhakkimuka) in all disputes between them, and then submit willingly to thy decisions" (4:65). The Prophet has also approved of arbitration; on at least three occasions the Prophet was informed of arbitration attempts by his Companions, Sa'd bin Mu'adh, al-A'war bin Bashamah, and Aba Shurayh Hani' bin Yazid, and was reportedly pleased when he heard that the parties concerned in each case had accepted the outcome of the process. ${ }^{74}$

\section{Amnesty ('Afwa)}

Amnesty and forgiveness are the means in Islamic theology and law - as also in most other world traditions - of relieving someone from punishment, blame, civil liability or religious penalty. It is also a recognised means of overcoming conflict and paving the way for peace. Whereas Christianity primarily conceives of forgiveness as a moral and religious imperative, Islam adds a legal dimension: it affirms it as a noble course of action, as a social good, and a means of peacemaking. For instance, Islamic conflict resolution in the context of homicide and bodily injury assigns a role for granting forgiveness to either the victim of the crime or his/her family. The Qur'an and hadith consistently hold out forgiveness as the preferred option.

Being the subject of over 30 verses in the Holy Book, forgiveness ('afwa) plays a role in ending legal disputes. While speaking of just retaliation (qisas) as a right of the crime victim and his/her family, the Qur'an follows on to declare that "if the family of the slain grants forgiveness, he may be compensated with handsome gratitude in a decent manner" (2:178). The text then warns that, after 
granting forgiveness, there must be no vengeance or aggression; everyone must make sure that the conflict comes to an end. ${ }^{75}$

The Qur'an often praises those who take a forgiving attitude, speaking of 'afwa as a manifestation of ihsan (beauty, beneficence - al-Baqarah, 2:178). God also speaks of His love for those who forgive without vindictiveness, especially when they are overwhelmed with the urge for revenge (Aal-'Imran, 3:134).

The recompense of an injury is an injury the like it, but whoever forgives and makes reconciliation, his reward is with God; and God loves not those who do wrong. (al-Shura, 42:40)

But (remember) one who endures with fortitude and forgives, that indeed is the most distinctive of all deeds. (Q 42:43)

Hold to forgiveness, enjoin kindness, and turn away from the ignorant. (al-A'raf, 7:199).

Pardoning is especially meritorious for someone who can avenge but chooses to exonerate and forgive. Yet Islam also puts a high premium on justice demanding sternness, especially from a leader or judge. Justice and amnesty often moderate and temper one another but can also conflict. To quote the Qur'an:

God commands justice ( $a l$ - 'adl) and the doing of good (al-ihsan) and generosity to one's kindred, and He forbids indecency, wrongdoing and oppression. (al-Nahl, 16:90)

In this verse, justice is enjoined side-by-side with ihsan, which seems to imply that it is not always a measure-for-measure justice that is desired; justice should be tempered, whenever appropriate, by ihsan, which in this context subsumes amnesty and forgiveness. Punishing the wrongdoer is the normal course enjoined by the Shariah, but amnesty may be preferable at times. Amnesty and forgiveness can play a vital role in post-conflict situations, such as those that now obtain in Iraq, Afghanistan, Libya and many other post-Arab Spring scenarios. The priority in post-conflict situations may to be to bring peace and facilitate an environment in which people can leave the torments of the past behind in the hope of building a stable future. Certainly, normal rules of law may be difficult to apply due to difficulties in evidence and proof and other factors - hence the special relevance of forgiveness.

\section{Counselling (Nasihah)}

Counselling (nasihah) is a Qur'anic principle that consists of giving sincere advice to another person or persons (including disputing parties) in an effort 
to resolve differences. It is also a recognised method within the rubric of alternative dispute resolution (ADR), especially in commercial disputes outside the courts' jurisdiction. Yet nasihah is a broad concept that cannot be confined to any particular context. Indeed, nasihah characterises Islam itself, as the proclamation found in a renowned hadith attests: "religion is good advice - aldinu al-nasihatu." ${ }^{.76}$ As a method of dispute resolution, nasihah consists of giving constructive professional advice that guides conduct and recommends a solution to resolve disputes. Although acting upon that advice is recommended, it remains essentially optional.

In order for nasihah to be acceptable and effective as a dispute resolution mechanism, certain rules need to be followed: a) nasihah should not be given in a manner that implies accusing any of the disputing parties; b) one should not expect any of the conflicting parties to comply with a given nasihah instantly or expect specific results; c) nasihah should be given in its proper context, paying attention to place and time and also to the right manner of delivery; d) the counselor should be knowledgeable in the subject matter of the dispute and be able to offer useful advice. Nasihah may be offered by community leaders, Imams or Muslim counselors, social workers, and professional counselors, all of whom could provide early intervention and advice in order to prevent a problem becoming larger, more damaging, or intractable.

The Islamic nasihah differs from mainstream counselling because it is based on the embedded perception of a common belief system - Islam - shared by both the advisee(s) and the counsellor. This shared understanding should ideally create a trusting relationship between all parties, often inspiring the advisee(s) to attempt a peaceful and amicable resolution of a particular dispute.

\section{Truce (al-Hudnah)}

Literally, Hudnah (also known as muwada'ah - mutual abandonment) means stillness after turbulence or excitement. Juridically, it has been variously defined by the different Islamic law schools. The Hanafi school, for example, defines Hudnah as an agreement/contract to cease fighting for a stated period, with or without financial consideration, when the Imam (head of state) deems it to be of benefit. Other schools concur, but add that Hudnah is signed only with a warring party (Shafi'i) and with non-Muslims (Hanbali). ${ }^{77}$

The legality of a truce is established by the Qur'an (al-Tawbah, 9:4; al-Anfal, 8:61; al-Ma'idah, 5:1). The truce of Hudaybiyyah, which the Prophet signed with the pagans of Mecca in the year $5 \mathrm{~A} . \mathrm{H}$, also proves the validity of Hudnah. Truces may be concluded with non-Muslims (including apostates who have renounced Islam), rebels and mutineers. This is with the proviso, however, that the latter group are not entitled to any financial consideration. 
For a truce to be valid, it must meet the following conditions: 1) that the Imam or his deputy ratifies it. Although this is the majority (Jumhur) position, the Hanafi's hold that Hudnah may be signed by any group of Muslims - just as a pass of safe conduct (aman) may be signed by any Muslim citizen; 2) that the truce is for the benefit (maslahah) of Muslims and fulfils a valid Shariah purpose; 3 ) that it is for a specified period. Although this condition is not agreed upon by all the schools, the majority (Maliki, Shafi'i and Hanbali) maintain that it should be neither open-ended nor permanent. Only the Hanafis validate a truce that is not time-bound; and 4) that it is not contingent on an unlawful condition that violates Shariah. ${ }^{78}$ This last condition may, however, be disregarded in the event of necessity (darurah). Hence a condition, such as payment of a financial consideration to the disbelievers, may be agreed to when necessary, but it would be deemed illicit otherwise. ${ }^{79}$

As for the consequences of a truce, it is generally agreed that a valid truce binds all Muslims, their Imam and his successors (if any). It accords safety and protection to all its counterparties, their persons and properties. Muslims are also required to be amicable and fair with the counterparties, both in word and act, and refrain from harming or humiliating them in any way, especially if they happen to be Muslims. Only when the signatories commit acts of treachery or openly violate the terms of the agreement can the Imam revoke the truce. Whereas blasphemy (such as insulting the Prophet Muhammad) amounts to a breach of truce according to the majority, the Hanafis hold that it does not. ${ }^{80}$ The truce comes to an end either upon expiry (if time-bound) or upon its termination by the Imam.

\section{Islamic Legal Maxims}

We now present a selection of Islamic legal maxims relating to peace, illustrating how the juristic tradition lends support to its promotion:

- Human dignity is a foundational purpose of the Shariah.

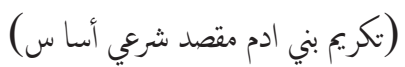

- The norm with regards to life, property and honour is inviolability.

$$
\text { (الأصل في الدماء والأموال والأعراض العصمة) }
$$

- Avoidance of hostility is, as far as possible, an obligation.

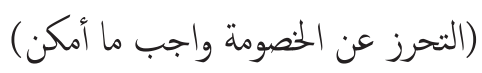


- Everything which causes sedition/tumult is impermissible.

$$
\text { (كل ماكان سببا للفتنة فإنه لايجوز ) }
$$

- Elimination of injustice is, as far as possible, an obligation.

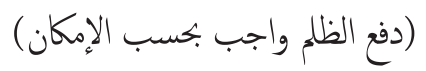

- Elimination of harm is, as far as possible, an obligation.

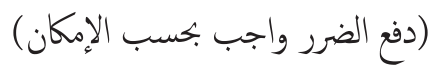

- Settlement/cessation of a dispute is, as far as possible, an obligation.

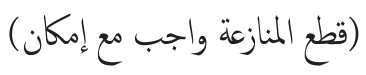

- The principle of reciprocal treatment among nations is bound by considerations of moral virtue.

$$
\text { (مبدأ التعامل بالمثل بين الدول مقيد بالفضيلة) }
$$

- The obligation of jihad partakes in the obligation of means, not of ends and purposes.

(وجوب الجهاد وجوب الوسائل لا المقاصد)

- Shariah advocates equality among people unless there be evidence to justify an exception.

$$
\text { (الثريعة سوت بين الناس إلا ما قام الدليل على تخصيصه) }
$$

- Muslims, dhimmis and temporary residents are all equal in respect of enacted rights that protect them against harm.

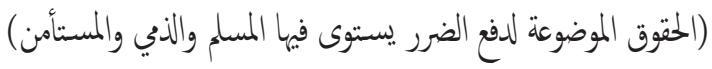

- Peace among Muslims is permissible provided that it does not turn the lawful into unlawful and vice versa.

$$
\text { (الصلح جائز بين المسلمين إلا صلحا أحل حراما أو حرم حلالا) }
$$

- When defence is possible by lighter means, the more difficult/heavy ones may not be attempted.

$$
\text { (متى أمكن الدفع بأسهل الوجوه لم يعدل إلى أصعبها) }
$$

- The norm is absence of hostility.

$$
\text { (الأصل عدم العدوان) }
$$


- The norm is absence of treachery.<smiles>[14CH3][Mg][AlH2]</smiles>

- Liability [for compensation] falls on the aggressor.

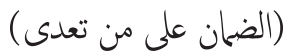

- Aggression does not acquire a right for the aggressor.

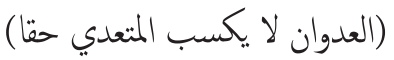

\section{Conclusion and Recommendations}

In this article, we have explored the many distinguishing features of peacemaking in the Islamic tradition. We have seen a vision of Islam as a religion of peace and justice, with an emphasis on equitable approaches to economic and political development, a qualified affirmation of cultural and religious diversity within the larger rubric of human fraternity, peace-making through non-violence, peace through equity, peace through conciliation, and an optimistic conception of human responsibility and potential. The evidence presented lends support to the following conclusions and recommendations:

- The pathways to peace-making expounded here should be practiced, as far as possible, by Muslim individuals, communities and leaders. History shows that Muslims are strongest when they are true to their principles. Values must therefore guide conduct if the latter is to be effective. Certainly, Islam is both faith and action ('aqidah wa' 'amal); the one without the other is incomplete and inconsequential.

- Our understanding of Islam should be inclusive of its broader objectives and purposes, not constrained by the rigidities of literalism and/or divisive scholasticism. The Sunni-Shia conflict clearly stands in contrast with Islam as a religion of peace and unity.

- Good governance, social justice and the rule of law are strongly conducive to normalcy and peace. These, however, are the very areas which require the most attention in many present-day Muslim countries. Governments in Muslim countries should therefore commit themselves on these fronts, as part of key performance indices that can measure progress on a regular basis.

- Muslim individuals and communities must engage in only peaceful jihad, such as fighting illiteracy, disease, environmental degradation and other social ills. Military jihad is today the assignment of professional armies. 
- In the era of globalisation, domestic peace is often inseparable from international peace. Yet, Muslim societies are most often afflicted with domestic conflicts. Peace from within must therefore be given priority over external affairs.

- Major international actors must bear greater responsibility for acting in the best interests of all and letting their policies be guided by ethical norms, not nationalist and/or protectionist interests that tend to widen inequality and poverty levels worldwide.

- The use of force as a last resort is inevitable when confronting rampant terrorism. Yet it has become patently obvious that violence breeds violence. Negotiated political settlements informed by ethical norms and justice, and not military force, are indispensable and should be prioritised during efforts to uproot international terrorism.

- Sufism can transcend the barriers that divide humanity. Muslim communities and their leaders should utilise the resources of this rich tradition in order to bring their own people closer together and improve the climate of understanding between communities and nations.

\section{Notes}

* Mohammad Hashim Kamali, Founding CEO of IAIS Malaysia, graduated from Kabul University, and took his $\mathrm{PhD}$ in Islamic and Middle Eastern Law at the University of London in 1969. Professor Dr M. H. Kamali served as Professor of Islamic Law and Jurisprudence at the International Islamic University Malaysia (IIUM, 19852007), then Dean of the International Institute of Islamic Thought and Civilization (ISTAC). He also held Visiting Professorships at McGill University's Institute of Islamic Studies; Capital University, Ohio; and the Wissenschaftskolleg, Berlin. A member of the Constitution Review Commission of Afghanistan (2003), he has provided expert legal consultation to the new constitutions of Iraq, the Maldives and Somalia. Eminent authority on Islamic legal studies, he has published over 170 academic articles and 35 texts, including standard textbooks at universities worldwide. He can be contacted at ceo@iais.org.my.

1. Cf., Nathan C. Funk and Abdul Aziz Said, Islam and Peacemaking in the Middle East, Boulder- Colorado \& London - UK: Lynne Rienner Publishers Inc., 2009, p. 130.

2. Cf., Seyyed Hossein Nasr, "Islam and the Question of Violence," in ed., Aftab Ahmad Malik, With God on Our Side, Policies and Theologies of the War on Terrorism, Bristol, UK: Amal Press, 2005, p. 273.

3. "Al-Salam" is, moreover, one of the ninety-nine Most Excellent Names (alasma' al-husna) of God that occur in the Qur'an. These are descriptive of the illustrious Self of God, the way that God makes Himself known to His human servants. 
4. Cf., Asna Husin, “Acehnese Women Struggle for Peace and Justice: Challenges and Opportunities," Islam and Civilisational Renewal, Vol.6, no.3 (July 2015), pp. 319-320.

5. Cf., Mahmoud Zakzouk, On Philosophy, Culture and Peace in Islam, ed., Andreas Bsteh, published as English tr. from German, New Delhi: Vikas Publishing House, 2004, pp. 126-7.

6. Ibn Taymiyyah, "Qa'idah fi Qital al-Kuffar," quoted in Majid Khadduri, The Islamic Law of Nations: Shaybani's Siyar, Baltimore: The John Hopkins University Press, 1966, p. 59.

7. Ibn Qayyim al-Jawziyyah, Ahkam al-Dhimmah, ${ }^{\text {rd }}$ ed., Subhi al-Salih, ed., Beirut: Dar al-'Ilm li'l-Malayin, 1983, 1:17.

8. Paul Hedges, “The need for religious literacy," Kuala Lumpur: New Strait Times, August 31, 2015, p. 29.

9. See details Andrew C Hess, "Millet," The Encyclopedia of Modern Islamic World, Vol. 3, p. 107.

10. See for details Ibrahim Kalin, "Islam and Peace: A Survey of the Sources of Peace in the Islamic Tradition," in ed., Qamar-ul Huda, Crescent and Dove: Peace and Conflict Resolution in Islam, Washington D.C: United States Institute of peace, 2010, p. 19.

11. Hedges, p. 29.

12. Cf. Mahmoud Zakzouk, On Philosophy, p. 115.

13. Sachiko Murata and William C. Chittick, The Vision of Islam, New York: Paragon, 1994, p. 309.

14. Cf., Ayse Kadayifci-Orellana and Meena Sharify-Funk, "Muslim Women Peacemakers and Agents of Change," in ed Qamarul Huda, Crescent and Dove: Peace and Conflict Resolution in Islam, Washington DC: United States Institute of Peace, 2010, p. 190.

15. Cf., Major Leon "Bogo" Cornwall, "The Socio-Political and cultural Implications of Monotheism in a Conflict-Ridden world," The Cordoba Seminar Series Papers, London: The Cordoba Foundation and Muslim Centre, February 2010, p. 11.

16. Cf., Seyyid Hossein Nasr, The Heart of Islam, 2002, p. 221; \& Funk and Said, Islam and Peacemaking, p. 216.

17. Cf., Kalin, "Islam and Peace," p. 24.

18. The term Islamicate suggested the hybrid and multifaceted nature of Islamic civilisation, as many previously non-Islamic elements were incorporated into Islamic civilisation in a relatively short period of time. See Marshall Hodgson, The Venture of Islam, Chicago: University of Chicago Press, 1974.

19. Kalin, "Islam and Peace," p. 27.

20. See for details Funk and Said, Islam and Peacemaking, 220f.

21. See Arthur Hyman, "Jewish Philosophy in the Islamic World," in S. H. Nasr and Oliver Leaman, eds., History of Islamic Philosophy, London: Routledge, 1996, 677; Kalin, "Islam and Peace," pp. 27-28.

22. Cf., Kalin, "Islam and Peace," p. 29.

23. Cf., Sachiko Murata and William C. Chittick, The Vision of Islam, New York: Paragon, 1994, p. 267.

24. Gandhi as quoted by Cornwall, "The Socio-Political and Cultural Implications 
of Monotheism," p. 10.

25. Cf. Asma Afsaruddin, "Recovering the Early Semantic Purview of Jihad and Martyrdom: Challenging Statist Military Perspectives," in ed. Qamar-ul Huda, Crescent and Dove, p. 43.

26. See Ibn Abi al-Dunya, al-Sabr Wa'l-Thawab 'Alayhi, ed. Muhammad Khayr Ramadan Yusuf, Beirut: Dar Ibn Hazm, 1997, p. 85.

27. Ibn Abu al-Dunya, Sabr, p. 85

28. Ibid., p. 51.

29. See Qamar-ul Huda, ed., Crescent and Dove, Introduction, p. xix.

30. See for details, Zeki Sartoprak, "Badiuzzaman Said Nursi's Paradigm of Islamic Nonviolence," in Qamarul Huda, ed., Crescent and Dove: Peace and Conflict Resolution in Islam, Washington DC: United States Institute of Peace, 2010, p. 102.

31. Ibid., p. 103.

32. Badiuzzaman Said Nursi, "The Voice of Truth," Volkan, Istanbul, March 27, 1909 as quoted in Sartoprak at "Nursi's Paradigm," p. 101.

33. Cf. Sartoprak, "Nursi's Paradigm," 100f.

34. Ibid., p. 104.

35. Ayse Kadayifci-Orellana and Meena Sharify-Funk, "Muslim Women", p. 194.

36. Mohamed Abu-Nimr, "An Islamic Model of Conflict Resolution," in ed., Qararul Huda, Crescent and Dove, p. 77; Chandra Muzaffar, Religion Seeking Justice and Peace, Penerbit Universiti Sains Malaysia 2010, p. 77.

37. See Asma Afsaruddin, "Recovering the Early," p. 189.

38. Muzaffar, Religion Seeking Justice, p. 78.

39. Funk and Nathan, Islam and Peacemaking, p. 185.

40. Cf., Nathan and Said, Peacemaking, p. 186.

41. All of the 24 verses of relevance to jihad can be found in Cherif Bassiouni and Amna Guellali, eds., Jihad and Its Challenges to International and Domestic Law, Hague Academic Press, The Hague, 2010, pp. 126-127.

42. Muhammad Sa'id Ramadan al-Buti, Jihad fi'l-Islam, Beirut, Dar al-Fikr 1995, p. 16.

43. 'Abd al-Rahman al-Mubarakfuri, Tuhfat al-Ahwadhi bi-Sharh Jami' al-Tirmidhi, ed. By 'Abd al-Rahman 'Uthman, Cairo, Matba' at al-Marifa [n.d.] Hadith No. 1671.

44. Ibn Majjah, Sunan Ibn Majjah, Kitab al-fitan. Bab al-Amr bi'l-Ma'ruf wa'lNahy 'an al-munkar, Hadith No. 4011. Abu Dawud and Tirmidhi have recorded a slightly different version of this Hadith which mentions, the word ' $a d l$ ' (justice) instead of ' $h a q q$ ' (truth).

45. Mubarakfuri, Tuhfat al-Ahwazi, p. 250.

46. Muslim, Mukhtasar Sahih Muslim, p. 469, Hadith No. 1756.

47. A J Wensinck, Al-Mu'djam al-Mufahras li-Alfäz al-Hadìth al-Nabawì, vol. 1, Leiden: E J Brill, 1967, p. 389.

48. Ibid.

49. 'Abd al-Razzaq, al-San'ani. Al-Musannaf, vol. 5, Beirut: DKI, nd., p. 271-272.

50. Muhammad Ibn Isa Al-Tirmidhi, Sunan al-Tirmidhi, Vol 4, hadith no: 2647, Cairo: Darul Al-Hadith, 2005, p. 454.

51. Ibn Hazm al-Zahiri, Kitab al-Fisal fi'l-Milal wa'l-Ahwa' wa'l-Nihal, Cairo: al- 
Matba'ah al-Adabiyyah, 1321/ 1942, 4:135.

52. Cf., Manzooruddin Ahmad, Islamic Political System in the Modern Age (Karachi, Royal Book Company 1983) p. 185.

53. See Mohammad Hashim Kamali, Law in Afghanistan, Leiden: E.J. Brill, 1985, p.7.

54. Bassiouni, Jihad and its Challenges, p. 140.

55. Muhammad Abu Zahrah, Nazarijyat al-Harb fi'l-Islam [The Theory of War in Islam], Cairo, Dar al-Qahirah lil-Taba'ah, 1380/ 1961, pp. 24-25.

56. Cf., Mohammad Hashim Kamali, Principles of Islamic Jurisprudence, (Cambridge, Islamic Texts Society 2003) pp. 202-228.

57. Ali A. Mazrui. 'The Ethics of War and the Rhetoric of Politics: The West and the Rest,' Islamic Millennium Journal (2002) p. 1.

58. Ibid., pp. 3-4. Ali Mazrui mentions in this connection many leading nonWestern personalities, including Mahatma Gandhi, Albert Luthuli, Anwar Sadat, Desmond Tutu, Nelson Mandela, and Kofi Annan, whose advocacy of peace echoes the spirit of Christian teachings better than most mainstream Christian themselves (Mazrui, ibid., p. 7).

59. Q Aal-'Imran, 3:110.

60. For details on Social Justice in Islam, see Mohammad Hashim Kamali, Freedom, Equality and Justice in Islam, Cambridge: Islamic Texts Society, 2000, 133-43.

61. Cf., AbdulHamid A. AbuSulayman, The Islamic Theory of International Relations: New Directions for Islamic Methodology and Thought, Herndon, Va: International institute of Islamic Thought, 1987, p. 20.

62. Cf., Joel Howard, "Warfare in the Qur'an" in eds., Ghazi bin Muhammad et al, War and Peace in Islam, p. 47.

63. This wider concept of peace has gained further ground since the so-called post-Cold War Washington New Consensus, which holds that elimination of violence has become more challenging since the 1990s "without major structural international change and deeper forms of justice." See Oliver R. Richmond, "The changing concept of peace building," Kuala Lumpur: News Straits Times, December 29, 2015, p. 16.

64. Ibn Rushd al-Qurtubi, al-Muqaddimat al-Mumahhidat, 2:515 as quoted in Mawsu'ah Fiqhiyyah, Vol. 27:325.

65. Muhammad ibn Hibban, Sahih Ibn Hibban, Beirut: Mu'assasah al-Risalah, 1988, hadith no. 5182 .

66. Cf., "Sulh," in al-Mawsu'ah al-Fiqhiyyah, vol.27: 335-337 at p. 336.

67. Cf., Ibid., Vol.27, pp.323-357; Musa Furber, “Alternative Dispute Resolution," Tabah Analytic Brief, No, 11, 2011: Tabah Foundation, Abu Dhabi, U.A.E., p.2. For details, Furber refers the reader to al-Sarqawi's commentary on Zakariyya al-Ansari's, Hashiyat al-Sharqawi 'ala Tuhfat al-Tullab: Cairo: Mustafa al-Babi al-Halabi, 1941, 2:64.

68. Furber, "Alternative Dispute Resolution,” p. 9.

69. Quoted in al-Mawsu'ah al-Fiqhiyyah (Kuwait), "Sulh," Vol.27, p. 327.

70. Cf., "Takhim" al-Mawsu'ah al-Fiqhiyyah, Kuwait: Wizarat al-Awqaf wa'lShu'un al-Islamiyyah, 10:233-34.

71. Muhammad Amin ibn 'Abidin, Hashiyah Radd al-Mukhtar 'al Durr al-Mukhtar, 8 vols. $3^{\text {rd }}$ ed., Cairo: Maktabah Mustafa al-Babi al-Halabi, 1984, 5:428. 
72. Ibid., 10:240.

73. "Tahkim," al-Mawsuah, 10:238-241.

74. Ibid., 10:235.

75. See for details Mohammad Hashim Kamali, "Amnesty and Pardon in Islamic Law: with Special Reference to Post-Conflict Justice." Islam and Civilisational Renewal, vol.6, no.4 (2015), pp. 442-467, at 447f.

76. Muslim, Mukhtasar Sahih Muslim, p. 329, hadith no. 1209.

77. Wizarat al-Awqaf wa'l-Shu'un al-Islamiyyah(Kuwait), al-Mawsu'ah alFiqhiyyah, Vol. 42, pp. 205-231 at pp. 205-206.

78. Ibid., pp. 207-213.

79. Ibid., p. 217.

80. Ibid., p. 227. 